\title{
Kritinès saugumo studijos XXI amžiuje: kur kreipti Lietuvos saugumo politikos tyrimus?
}

\begin{abstract}
Šiame straipsnyje pristatomi naujausi saugumo studijų tyrimai ir diskusijos, siekiant pasiūlyti naujų, kitokių gairių Lietuvos saugumo politikos tyrimams. Tekste iš pradžių aptariami pagrindiniai klausimai, ị kuriuos remiasi šiuolaikinès diskusijos dèl saugumo, tada yra įvertinama ir apžvelgiama kritinè saugumo studijų tradicija, kuri formuluoja mąstymo prielaidas ir įrankius konkretiems saugumo klausimams analizuoti ir skatina reflektyvistinį mąstymą apie saugumą. Trečioji straipsnio dalis skiriama trims reprezentatyvioms saugumo tyrimų temoms (saugumo analizei per rizikos, ypatingumo ir medijų sąveiką), itin suaktualejusioms pastaraisiais metais, ir saugumo studijoms siūlančioms inovatyvių ǐžvalgų.
\end{abstract}

\section{Ivadas}

Koks yra saugumo politikos rūpestis, kokia ji turètų būti, kaip mąstyti apie saugumą - šie ir panašūs klausimai rūpi ir politikos praktikams, ir politikos analitikams visame pasaulyje. Mūsų šalyje refleksijos apie saugumą sietinos su dviem procesais. Pirmasis - tai Lietuvos valstybès atkūrimas ir siekiai suvokti ir įvertinti savo saugumo situaciją, kuri lyg ir nurodè temas, apie kurias reikia mąstyti, ir klausimus, kurių prasminga klausti. Tačiau šie bandymai negalèjo būti atsieti nuo pastangų ísigilinti į vakarietiško mąstymo apie saugumą tradicijas, ginčus ir atsakymus (antrasis procesas). Būtent antrojo proceso rezultatas buvo žodynas, leidžiantis kalbèti apie saugumą po Šaltojo karo, analizès įrankiai ir naujos teorinès pozicijos. Lietuvos situacijai gerinti pradètos taikyti nacionalinio, kolektyvinio saugumo idejos, pradèta diskutuoti apie saugumo bendruomenès, strateginès kultūros kūrimą, formuluota apsisaugojimo nuo grèsmių koncepcija, diskutuota apie mažos valstybės saugumo politikos galimybes, mokytasi pagrindinių tarptautinių santykių disciplinos, saugumo studijų sąvokų ir susipažinta su tradicijomis.

\footnotetext{
* Dr. Dovile Jakniūnaité - Vilniaus universiteto Tarptautinių santykių ir politikos mokslų instituto docentè. Adresas korespondencijai: Vokiečių 10, 01130Vilnius, tel. (8 5) 251 4137, el. p. dovile.jakniunaite@tspmi.vu.lt.
} 
Akademinès saugumo studijos Vakaruose pakito, nes turèjo būti iš naujo ịvertinta ir suprasta pakitusi Šaltojo karo aplinka. Paskutiniajame XX a. dešimtmetyje itin suintensyvejo teoriniai ginčai, kaip geriau analizuoti saugumą, ir apskritai, kas yra tokių studijų objektas. Diskutuota apie saugumo sąvokos plètimą, jos objektų skaičiaus didinimą, ginčytasi dẻl saugumo sektorių, regioninių saugumo kompleksų idejjos taikymo. Šiuos dalykus vèliau kuriam laikui užgožè sugrèsminimo teorija ir sugrèsminimo proceso analizè. ${ }^{1}$

I šią audringą diskusijų erdvę Lietuvoje iš pradžių žiūrèta iš toli ir įžengta nedrąsiai, visų pirma užsiimant bazinių idèjų pristatymu ir jų iš pradžių gana nesudètingu taikymu Lietuvoje. ${ }^{2}$ Stiprų postūmị mąstant apie saugumo studijas padarė Barry'io Buzano knygos „Žmonès, valstybè ir baimè: tarptautinio saugumo studijos po Šaltojo karo" vertimas ị lietuvių kalbą ${ }^{3}$. Ši knyga visai saugumo studijų disciplinai (ypač Europoje) išlieka vienu svarbiausių ịvadinių tekstų apie nacionalinị ir tarptautinị saugumą. Šia knyga pereita nuo siauro, karinio, požiūrio prie platesnio požiūrio ị saugumą . Lietuvoje ši knyga buvo ne tik pirmieji saugumo studijų teoriniai pagrindai, bet ir paskata pradèti inovatyvius sektorinius saugumo tyrimus. ${ }^{4}$ Pačioje dešimtojo dešimtmečio pabaigoje Lietuvoje prasidejo ir sugrèsminimo studijos, tuo laiku vis labiau populiarejjusios visoje Europos saugumo tyrejjų bendruomenejje. Diskutuota tiek teoriniais klausimais, tiek atliekant empirinius Lietuvos saugumo politikos tyrimus, nustatant sugrèsminimo strategijas. ${ }^{5}$

Geopolitika buvo kita stipri teorinè tradicija, kuriai rūpejjo Lietuvos saugumo situacijos analizè. Jos atstovai, vertindami Lietuvos geografinę padètị, istorinę patirtị, iš dalies ir dabarties situaciją, siekẻ pagrịsti provakarietiškos užsienio ir saugumo politikos pasirinkimus ir pabrèžti vakarietiškos geopoli-

\footnotetext{
${ }^{1}$ Buzan B. \& Hansen L., The Evolution of International Security Studies, Cambridge: Cambridge University Press, 2009.

${ }^{2}$ Bagdonavičius V., sud., Lietuvos nacionalinis saugumas: teorija ir realijos, Vilnius: Filosofijos, sociologijos ir teisès institutas, 1994; Vèliau pasirodè: Vareikis E ir kt.., Skaitiniai apie nacionalinị ir tarptautinị saugumą, T. 1, Vilnius: Ogamas, 2000; Prazauskas A., Bajarūnas E., \& Žulys A., Skaitiniai apie nacionalinị ir tarptautini sauguma, T. 2, Vilnius: Ogamas, 2001.

${ }^{3}$ Buzan B., Žmones, valstybe ir baimè: tarptautinio saugumo studijos po Šaltojo karo, Vilnius: Eugrimas, 1997; anglų kalba Barry B., People, States, and Fear, 1991.

${ }^{4}$ Jurgelevičiūtė D., Saugumo samprata informacijos amžiaus tarptautiniuose santykiuose, Vilnius: VU TSPMI bakalauro darbas, 2004; Jurgelevičiūtė D., “The Issue of Occupation in Lithuanian-Russian Relations: Information Security Aspects," Lithuanian Foreign Policy Review 18 (2), 2006, p. 56-82; Janeliūnas T., „Gegužès 9-osios problema saugumizavimo teorijos ir komunikacinio saugumo požiūriu“ Politologija, 2, 2005, p. 3-30.

${ }^{5}$ Miniotaite G., “The Security Policy of Lithuania and the 'Integration Dilemma”, COPRI Working Papers 5/2000, Copenhagen: Copenhagen Peace Research Institute, 2000; Miniotaitė G., Jakniūnaitè D., „Lietuvos saugumo politika ir identitetas šiuolaikinių saugumo studijų požiūriu“, Politologija, 3, 2001, p. 21-43; Janeliūnas, op.cit.; Jurgelevičiūtè, op.cit.
} 
tinės orientacijos privalumus ${ }^{6}$. Dar vieną saugumo studijų grupę sudare analitinio rekomendacinio pobūdžio tekstai, kuriais bandytos parodyti vienos ar kitos Lietuvos saugumo problemos ir jų sprendimo būdai. Tokie tekstai retai būdavo ịtraukiami ị išsamesnes saugumo studijų diskusijas, likdami politikos diskusijų erdveje.

Pastarụjų dešimties metų Lietuvos akademinių saugumo tyrimų mažèjimas susijęs su pasikeitusia politine situacija ${ }^{7}$. Narystès ES ir NATO padarè meškos paslaugą - dèmesys nukrypo ị šių institucijų veiklos analizę ir Lietuvos veikimo strategijas šiose organizacijose. Terorizmas, XXI a. pradžioje buvęs pagrindine tarptautinio saugumo tematika, ir jo tyrimai Lietuvai nebuvo itin aktualūs, o $2008 \mathrm{~m}$. prasidèjusi ekonominè krizè nukreipè tyrëjų dèmesị dar toliau nuo saugumo klausimų. Tad galima sakyti, kad pastaruosius kelerius metus Lietuvos akademinèje erdveje nepastebimi naujausi tyrimai, bandymai juos analizuoti, mažai diskutuojama apie šiuolaikinius saugumo iššǔkius, sèkmes ir nesèkmes, saugumo politikos pasekmes valstybėms, jos piliečiams ir tarptautinei aplinkai, metodologines problemas ar naujų įrankių taikymą.

Šiuo straipsniu pristatomi naujausi saugumo studijų tyrimai ir diskusijos, siekiant pasiūlyti naujų, kitokių jžvalgų Lietuvos saugumo politikos tyrimams. Tam straipsnyje yra apžvelgiami paskutinieji saugumo studijų tyrimai ir teoriniai ginčai. Iš pradžiu aptariami pagrindiniai klausimai, kuriais remiasi šiuolaikinès diskusijos apie saugumą. Tada yra ịvertinama ir apžvelgiama kritinè saugumo studijų tradicija, kuri formuluoja mąstymo prielaidas ir įrankius konkretiems saugumo klausimams analizuoti ir skatina refleksyvistinį mąstymą apie saugumą. Trečioji straipsnio dalis skiriama trims reprezentatyvioms saugumo tyrimų temoms (saugumo analizei per rizikos, ypatingumo ir medijų sąveiką), itin suaktualejusioms pastaraisiais metais ir saugumo studijoms, siūlančioms inovatyvių ižvalgų. Būtina pabrèžti, kad nei pasirinktos temos, nei aptariamos teorinès pozicijos, nei apžvelgiami konkrečių autorių darbai toli gražu neišsemia šiuolaikinių saugumo studijų. To negalètų padaryti nẻ vienas ìvadinis straipsnis. Tad pasirinkimas yra neabejotinai subjektyvus, tačiau kartu remiasi įsitikinimu, kad šių klausimų pristatymas Lietuvos metinés strateginés apžvalgos skaitytojams suteiks naujų idejų ir atvers gal kiek mažiau pažǐstamą kritinių saugumo studijų perspektyvą.

\footnotetext{
${ }^{6}$ Laurinavičius Č., Motieka E., Statkus N., Baltijos valstybių geopolitikos bruožai. XX amžius, Vilnius: Vilniaus istorijos institutas, 2005; Statkus N., Motieka E., Laurinavičius Č., Geopolitiniai kodai, Vilnius: Vilniaus universiteto leidykla, 2004; Motieka E. \& Statkus N., „Geopolitinių kodų struktūra ir dinamika“ Politologija, 2003, 29(1) p. 60110.

${ }^{7}$ Tiketina, kad $2014 \mathrm{~m}$. Ukrainos įvykiai greičiausiai paskatins diskusijas dèl informacinio saugumo. Bus įdomu stebèti, ar jos bus perkeltos į akademinę erdvę ar leis suformuluoti analitinių įrankių šiai sąvokai.
} 


\section{Saugumo tyrimų tradicija, plètra ir sugrèsminimas}

Siekiant suprasti pastarųjų dešimties metų tendencijas diskutuojant apie saugumą, pirmiausia reikia susigaudyti, kokiomis diskusijomis remiamasi ir $\mathfrak{i}$ ką nurodoma. Čia svarbūs trys dalykai - tradicinès saugumo sampratos kritika, saugumo sąvokos plettra ir sugrèsminimo teorijos įnašas. Diskusijos dèl šių klausimų, galima sakyti, apibrèžè pirmąji dešimtmetị po Šaltojo karo.

Tradicine saugumo samprata laikomas siauras, karinis požiūris ị saugumą, kai pagrindinis demesys yra rūpinimasis fiziniu valstybès, o ne kokio kito tarptautinių santykių subjekto, saugumu ir išlikimu. Pagal Stepheną Waltą, saugumo studijos tiria „sąlygas, kuriomis dideja jègos naudojimo tikimybè, būdus, kuriais jègos naudojimas veikia individus, valstybes, visuomenes, ir konkrečią valstybių politiką, kuria siekiama ruoštis, išvengti arba pradèti karą $^{\text {"8. }}$. Jis pabrèžè būtent karinị, materialistinị požiūrị ị nacionalinị saugumą ir saugumo dilemos ${ }^{9}$ vaidmenị valstybių santykiuose. Walto įsitikinimu nèra prasmès diskutuoti apie kitokias saugumo problemas, nes jos nutolina demesi nuo bazinių, esminių klausimų ir problemų.

Tradicine saugumo sąvoka yra pagrindinis atspirties taškas diskutuojant, ką ir kaip reikia keisti diskusijose apie saugumą, kartu ši sąvoka buvo ir yra labiausiai kritikuojama dèl savo siaurumo, dèl pernelyg didelio dèmesio prievartai, karui ir dèl mažejančio aktualumo. Manoma, kad toks požiūris šiuolaikinèje pasaulio politikoje nebetinkamas, nes keičiasi grèsmių pobūdis, riba tarp vidinių ir išorinių grèsmių vis labiau nyksta ir pati valstybè gali tapti grèsme saugumui.

Būtent šioje vietoje galime kalbèti apie sąvokos plètrą, kai žodị saugumas pradèta taikyti vis didesniam problemų skaičiui aprašyti (sąvokos „plètimas") ir pridedant daugiau saugumo objektų (nuo individualaus iki tarptautinio, globalaus saugumo (taip vadinamasis sąvokos "gilinimas") ${ }^{10}$. Tipinis šios tendencijos pavyzdys yra jau minèta Buzano knyga, kurioje jis skiria penkis saugumo sektorius (karinị, politinị, ekonominị, aplinkosauginị ir socialinị) ir kalba ne tik apie nacionalinį, bet ir individualų ir tarptautini saugumą ${ }^{11}$ Jo issitikinimu, būtent toks kompleksiškas požiūris geriausiai atspindi ir yra tinkamas situacijai po Šaltojo karo suprasti.

\footnotetext{
${ }^{8}$ Walt S.M., “The Renaissance of Security Studies," International Studies Quarterly 35 (2), 1991, p. 212.

${ }^{9}$ Saugumo dilema ịprasta apibūdinti situaciją, kai vieno subjekto siekis didinti savo saugumą sukuria nesaugumą kitam ir dèl to jị irgi skatina didesnị demesị skirti savo saugumui. Tokia situacija paprastai atveda ne prie saugumo, o prie nesaugumo situacijos.

${ }^{10}$ Krause, K. \& Williams, M. C., "Broadening the Agenda of Security Studies: Politics and Methods", Mershon International Studies Review, 40 (2), 1996, p. 229-254.

${ }^{11}$ Buzan, op.cit.
} 
Besiplètojant ginčams dèl to, kiek ir kurios problemos yra saugumo, kurios nusipelno jomis būti, o kurios ne, kas atsitinka, kai vis daugiau problemų tampa saugumo problemomis, kyla klausimas, o kaip mes atskiriame saugumo problemas ir kaip jas prioritetizuojame. Šis klausimas ir tampa sugrèsminimo teorijos esminiu rūpesčiu ir atspirties tašku. Tad trečioji teorinè tendencija, kurios negalima apeiti vertinant XX a. pabaigos diskusijas dèl saugumo - tai sugrèsminimo teorija. Ji siejama su Buzanu ir Ole Waeveriu bei Kopenhagos taikos tyrimų institutu, kuriame dirbo minèti ir kai kurie kiti pagrindiniai prie teorijos prisideję mokslininkai ${ }^{12}$. Sugrèsminimo teorija remiasi trimis esminèmis sąvokomis - sugrèsminimo ${ }^{13}$, saugumo sektorių ${ }^{14}$ ir regioninių saugumo komplek$\mathrm{sų}^{15}$. Sugrèsminimas yra labiausiai mokyklą išgarsinusi ir išskyrusi idejja.

Kai kalbama apie saugumo problemą, kalbama apie egzistencines grèsmes (t. y. apie tai, kas kelia didžiausią pavojų) kuriam nors objektui, kuris vadinamas referentiniu. Tai reiškia, kad siekiant tas grèsmes pašalinti yra leidžiama imtis ypatingų, už ịprastos politikos erdvès išeinančių priemonių. Norint suprasti saugumo politiką reikia suprasti, kas kalba ir kaip kalba. Taigi grèsmés kyla iš kalbinių praktikų, o pats saugumas yra kalbos aktas, kurị ištaria galias turintys veikejjai, dažniausiai politikai. Procesas, kurio metu tam tikros problemos, rūpesčiai per kalbos aktus virsta saugumo problemomis ir vadinamas sugrèsminimu. ${ }^{16}$

Pagal šią logiką nèra jokios prasmès ginčytis, ar grèsmès įvertintos objektyviai ar ne, prasmingiau yra suprasti grèsmių konstravimo procesą. Patys klausimai nèra savaime nei saugumo, nei nesaugumo. Itvardijus juos kaip tokius ir įtvirtinus ši ịvardijimą politinejje dienotvarkejje, jie tampa saugumo politikos dalimi su visomis ịprastomis pasekmèmis. Taigi sugrèsminimo teorija siūlo intersubjektyvų požiūrị i saugumą ir jo grèsmes. Tyrejai neklausia, ką reiškia saugumas, o analizuoja konkrečias lingvistines praktikas ir siekia suprasti, kaip kalbama apie saugumą.

Sugrèsminimo teorija privertè smarkiai suabejoti bepradèjusia įsigalèti nuostata, kad kuo daugiau saugumo problemų, tuo geriau ${ }^{17}$. Saugumo politi-

\footnotetext{
${ }^{12}$ Sugressminimo teorija dažnai vadinama ir Kopenhagos mokyklos teorija pagal vietą, kurioje ji susiformavo. Ṣ̌ vardą jai davè McSweeney'us. Be minètų mokslininkų prie Kopenhagos mokyklos teorijos plètotojų priskiriami Lene Hansen, Jaapas de Wilde'as.

${ }^{13}$ Waever O., "Securitization and Desecuritization" in R. D. Lipschutz, ed., On Security, Columbia University Press, 1995, p. 46-86.

${ }^{14}$ Aiškiausiai išplètota Buzan B., Waever O., \& Wilde de J., Security: A New Framework for Analysis, Boulder, CO: Lynne Rienner, 1997.

${ }^{15}$ Buzan B. \& Waever O., Regions and Powers: The Structure of International Security, Cambridge: Cambridge University Press, 2003.

${ }^{16}$ Išsamiau apie tai žr. Buzan, Waever \& Wilde, op.cit.

${ }^{17}$ Argumentuojant, kad tai, viena vertus, atspindi mūsų sudètingẻjantị pasauli, o, kita vertus, leidžia labiau atkreipti dèmesị ị egzistuojančias problemas.
} 
kos retorikos dominavimas sukuria nereikalingą ypatingumo situaciją, kelia itampą ir suteikia valstybei ar jos institucijoms itin didelę galią, kurios šiaip jau ịprastame demokratiškame politiniame procese nebūtų priimtinos. Todèl tam tikra prasme, saugumas - tai politikos nesèkmè, negebejjimas susidoroti su problemomis pagal ịprastas politines procedūras. Dèl to nugrèsminimas, ypač Waeverio įsitikinimu, turètų būti ilgalaikè strategija, reiketų siekti, kad problemos būtų sprendžiamos viešojoje erdveje, o ne gaminti vis daugiau saugumo klausimų ${ }^{18}$ Sugrèsminimo idejos populiarejjimas buvo labai susijęs su "konstruktyvistiniu posūkiu“ tarptautinių santykių disciplinoje. Aleksanderio Wendto garsioji fraze „anarchija yra tai, ką valstybès su ja padaro ${ }^{19}$ nubrèžè alternatyvų platų kelią tyrimams - siekti suvokti, kaip mes kaip tarptautinès politikos, saugumo veikejjai, kuriame pasauli per savo kalbą ir praktikas. ${ }^{20}$

$2001 \mathrm{~m}$. rugséjo 11-oji JAV, kai nuo teroristų išpuolių žuvo daugiau nei trys tūkstančiai žmonių, tapo kita simboline data, žymèjusia naują diskusijų dèl saugumo ir saugumo tyrimų etapą. Žinoma, ši data yra daugiau formalus ir kartu simbolinis pasirinkimas, nuo kurio tiesiog patogu vertinti paskutiniu metų saugumo studijų raidą. Teorinis mąstymas ir diskusijos retai būna taip aiškiai priklausomos nuo konkrečių istorinių îvykių. Tokie įvykiai daugiau yra tam tikras žymeklis, leidžiantis ryškiau nustatyti tendencijas, o ne brèžiantis aiškias diskusijų ribas. Kita vertus, refleksija to, kas ịvyko per 2001 rugsëjo 11-ąją, taip pat tolesnių, tačiau dèl 2001 rugsèjo 11-osios atsiradusių politinių sprendimų ir veiksmų vertinimas buvo svarbi paskata daugumai toliau aptariamų klausimų ir svarstymų. Todèl apžvalgoje koncentruojamasi ị pastarųjų maždaug penkiolikos metų saugumo tyrimus, kaip jau minèta, analizuojant kritinių saugumo studijų lauką.

\section{Kritiniai požiūriai ị saugumą}

Saugumo studijų laukas, galima sakyti, yra pasidalijęs $\mathfrak{i}$ dvi stovyklas - $\mathfrak{i}$ patarejų ir ị isteblišmento kritikų ${ }^{21}$. Saugumo studijos yra labai glaudžiai susijusi su politine praktika ir politikos kūrimu, saugumo analitikai nuo pat Šaltojo karo pradžios smarkiai prisideda prie saugumo politikos žodyno formavimo,

\footnotetext{
${ }^{18}$ Waever, „Securitization and Desecuritization“.

${ }^{19}$ Wendt, A., "Anarchy is What States Make of It: The Social Construction of Power Politics", International organization, 46 (2), p. 391-425.

${ }^{20}$ Išsamiau apie konstruktyvizmo įnašą žr. Jakniūnaitė D., Nekrašas E., „Kaip tirti tarptautinius santykius konstruktyvistiškai: filosofinių prielaidų ir teorinių nuostatų analizė", Politologija, 59 (3), p.29-58.

${ }^{21}$ C.A.S.E. Collective, “Critical Approaches to Security in Europe: A Networked Manifesto," Security Dialogue 37 (4), 2006, p. 462.
} 
prie saugumo politikos pagrindimo ir pateisinimo. ${ }^{22}$ Jei laikytumėmès tokios skirties, tai pirmoji stovykla dažniausiai sprendžia jau įsigalejusias saugumo problemas, laikosi objektyvistinio, racionalistinio požiūrio i̇ saugumą, daugumą politinių praktikų laiko duotybėmis ir daugiau mažiau palaiko sistemos status quo.

Robertas Coxas teorijas skirste $\mathfrak{i}$ problemas sprendžiančias ir kritines. Problemas sprendžiančios, pagal jit, priima kaip savaime suprantamus „egzistuojančius socialinius ir politinius santykius ir juos reguliuojančias

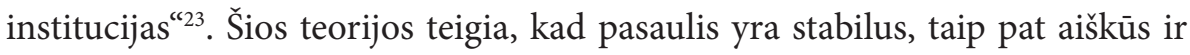
jame veikiantys veikejjai ir problemos, o tyrimų tikslas - padaryti taip, kad pasaulis veiktų tvarkingai, neužsikirstų. Pirmoji saugumo studijų stovykla kaip tik ir priklausytų Coxo problemas sprendžiančioms teorijoms. Šioje straipsnio dalyje pristatomos pagrindinès kritinès pozicijos, metančios iššūkị tradiciniams požiūriams. Kokių privalumų teikia kritinis, kitoks kalbejimas ir kodèl šiame straipsnyje koncentruojamasi i jị?

Kritinè analizė visų pirma reiškia abejonę nusistovejusiomis mąstymo tradicijomis ir prielaidomis, kuriomis šios remiasi. Neanalizuojant mąstymo prielaidų rizikuojama nepastebèti tam tikrų reiškinių, problemų. Teorijos ne tik apibūdina pasauli, jos kuria, apibrèžia savo analizès objektus, neịmanoma formuluoti vertybiškai neutralių žinių. Nurodydami, į ką reikia žiūrèti, ką analizuoti, apibrèždami analizès objektą, formuluojame ir savo teorines pozicijas. Teoretizavimas vyksta tam tikroje erdvejje tam tikru laiku ir priklauso nuo žmogaus kaip socialaus veikejo pozicijos (vietos, išsilavinimo, klasės, vertybių ir daugybès kitų savybių). Ir visa tai turi pasekmių. Dèl to Coxas teigè, kad "theory is always for someone and for some purpose ${ }^{\text {"24 }}$ (teorija visada yra reikalinga kam nors ir kieno nors tikslui pasiekti).

Kritines saugumo tyrimų perspektyvas jungia bendra nuostata ị saugumo praktikas žiūrèti kritiškai ir kartu refleksyviai, nepriimant politinio sprendimo prielaidų kaip nekvestionuotinų, analizuojant kaip per saugumo praktikas formuojasi ir isitvirtina tam tikri supratimai, nuostatos ir kokias pasekmes šie procesai sukuria. Dèl to straipsnyje koncentruojamasi $\mathfrak{i}$ kritinị kalbejjimą, kuris siekia atverti daugiau ir kitokių saugumo studijų erdvių. Kritinės pozicijos siūlo praktikams būti refleksyvesniais. Toks veiksmas pasiūlo būdus, kaip veikti ir mąstyti pliuralistinejje, prieštaringoje aplinkoje, kurioje yra skirtingos

\footnotetext{
${ }^{22}$ Lawrence P. K., "Strategy, Hegemony and Ideology: The Role of Intellectuals," Political Studies 154, 1996, p. 44-59.

${ }^{23}$ Cox R. W., "Social Forces, States and World Orders: Beyond International Relations Theory," Millennium, 10 (2), 1981, p. 128.

${ }^{24}$ Ibid.
} 
tiesos, daugybė teorijų ir žinojimo formų.

Šios perspektyvos atstovai tvirtina, kad saugumas yra antrinė sąvoka, kuri kyla ir yra neatsiejama nuo suvokimo, kaip veikia pasaulis ir kas yra politika. ${ }^{25}$ Iš tiesų nesunku sutikti, kad saugumas - tai grèsmių nebuvimas. Tačiau šis apibrěžimas yra apgaulingai paprastas. Kad išlaisvintumėme pasaulị nuo grèsmių, pirmiausia reikia žinoti grèsmes, kurių bandome atsikratyti. Taip pat reikia žinoti, ką saugome. Kritineje teorijoje individas tampa pagrindiniu referentiniu saugumo objektu. Dauguma problemų, apie kurias kalba saugumo sąvokos plètejjai, veikia visų pirma žmones, jų gyvenimus, o ne valstybes. Valstybės yra žmonių bendruomenės, dèl to ir žmonių saugumas turètų rūpèti pirmiausia.

Diskutuojant dèl dèmesio individui ir politinio grèsmių kūrimo pobūdžio dominuoja dvi diskusijų kryptys Velso ir Paryžiaus mokyklų ${ }^{26}$.

Velso mokykla siejama pirmiausia su Kenu Boothu ${ }^{27}$, taip pat Keith Krause, Mike'u Williamsu ${ }^{28}$, Richardu Wynu Jonesu ${ }^{29}$. Jie smarkiai kritikuoja tradicinị $\mathfrak{i}$ karinio saugumo ir konfliktų sprendimus orientuotą požiūrị. Idèja, kad karas yra esminè, pagrindinè tarptautinès politikos problema, pati yra itin problemiška. Tokia nuostata reiškia, jog daroma prielaida, kad pasaulis nekinta. Ir tokiu būdu pateisinamas egzistuojantis status quo. O nemažai daliai gyvenančių mažiau išsivysčiusiose valstybėse pati valstybe ir jos institucijos yra didžiausia grèsmė laisvèms ir saugumui, skurdo, nelaimių šaltinis. Dėl to Velso mokyklos teorija laikytina sąmoningai siekiančia pakeisti ne tik saugumo supratimą ir saugumo studijas, bet ir politinius saugumo veiksmus, kuri skatina ar net reikalauja galvoti ne apie valstybes, o apie individus, jų bendrabūvio kokybę ir apribojimų pašalinimą.

Velso mokyklos teorija išsiskiria dèmesiu emancipacijai, kuri laikoma saugumo studijų tikslu. Taip labai sąmoningai pasirenkama strategija ne tik analizuoti pasaulị, bet ir ji keisti. Jei ì pasauli žvelgiama per valstybès ir nacionalinio saugumo perspektyvą, ignoruojame valstybės, jų institucijų santykius su žmonėmis ir nepastebime, kad valstybė dažnai yra didžiausia proble-

\footnotetext{
${ }^{25}$ Pagal Peoples C. \& Vaughan-Williams N., Critical Security Studies: An Introduction, London and New York: Routledge, 2010, p. 22-23.

${ }^{26}$ Šiuos įvardijimus pasiūle Ole Waeveris, "Abersytwyth, Paris, Copenhagen: New 'Schools in Security Theory and Their Origins between Core and Periphery", presented at the Annual Meeting of the International Studies Association, Montreal, 2004.

${ }^{27}$ Booth K., "Security and Emancipation", Review of International Studies 17 (4), 1991, p. 313-26; Booth K., Theory of World Security, Cambridge University Press, 2007.

${ }^{28}$ Krause K. \& Williams M. C., "Broadening the Agenda of Security Studies: Politics and Methods," Mershon International Studies Review, 40 (2), 1996, p. 229; Krause K. \& Williams M. C., eds., Critical Security Studies: Concepts and Strategies, Routledge, 1997.

${ }^{29}$ Wyn Jones R., Security, Strategy and Critical Theory, Boulder, CO: Lynne Rienner, 1999.
} 
ma. O saugumas turi būti susijęs su „kūnišku, materialiu žmonių buvimu ir patirtimi“"30. Siekiant apeiti ị valstybę orientuotą mąstymą ir siūloma emancipacijos ideja. Boothas aiškina:

Saugumas reiškia grèsmių nebuvimą. Emancipacija yra žmonių (kaip individų ar grupès) išlaisvinimas nuo fizinių ir žmogiškųjų apribojimų, kurie neleidžia jiems elgtis laisvai. Karas, karo grèsmé, skurdas švietimo sistemos trūkumai, politine priespauda ir pan. yra tie apribojimai. Saugumas ir emancipacija yra dvi tos pačios monetos pusés. Ne galia, ne tvarka, o emancipacija sukuria tikrąj saugumą. Teoriškai, emancipacija ir yra saugumas ${ }^{31}$.

Kuo bus mažiau karo, skurdo, priespaudos, tuo žmonès bus laisvesni. Dèl šios priežasties saugumas turi būti gana plati sąvoka. Emancipacijos neịmanoma pasiekti, tai ne baigtinis procesas, net jei tvarka taps geresné, emancipacija nebus absoliuti. Saugumas turi būti susijęs su realiais žmonėmis, tad saugumo studijos turi atskleisti aplink egzistuojančius suvaržymus, kliūtis, trukdančias žmonių veikimui ir raiškai. Saugumo studijos turi analizuoti suvaržymus palaikančias praktikas.

Velso mokyklos teorija, nors ir keičia saugumo referentą, saugumo sąvoką, visgi, vartoja ịprasta klasikine reikšme - tik ja siekiama nustatyti tikrąsias grèsmes žmogui, o ne tariamas, valstybėms rūpinčias grèsmes. Dèl to kartais ši tyrimų tradicija pradeda panašèti ị objektyvistinę teoriją, tik besiremiančią kitomis normatyvinėmis prielaidomis. Kita vertus, tai neabejotinai pasipriešinimą skelbianti pozicija, sąmoningai siekianti atstovauti žmonėms, kurių balsai nėra girdimi, kuriems niekas neatstovauja, kurie neturi galios.

Paryžiaus saugumo tradicija siejama su Didieriu Bigo ${ }^{32}$, Jefu Huysman$\mathrm{su}^{33}$ ir žurnalu Cultures et Conflits. Kitaip nei Velso mokyklos metateoretizavimas, ši pozicija užsiima išsamiais empiriniais tyrimais: analizuojama, kaip veikia ịvairios saugumo agentūros, kaip jos formuluoja oficialų saugumo diskursą ir reguliuoja procesus; atskleidžiama, kaip smarkiai yra susijęs vidinis ir išorinis saugumas, kaip ịvairios įstaigos konkuruoja ir kuria naujus grèsmių vaizdinius, ypač per kalbejjimą apie imigraciją, organizuotą nusikalstamumą, terorizmą ${ }^{34}$. Bigo tvirtina, kad taip kuriamas ne saugumas, o nesaugumas (angl. insecurity), kuris yra bendrai ir saugumo politikos (angl. policy), ir saugumo diskurso rezultatas. Biurokratinių veiksmų analizè yra itin puikus būdas

\footnotetext{
${ }^{30}$ Ibid, p. 23.

${ }^{31}$ Booth, "Security and Emancipation", p. 319.

${ }^{32}$ Bigo D., Polices en Réseaux. Lexpérience Européenne, Paris: Presses de Sciences Po, 1996.

${ }^{33}$ Huysmans J., The Politics of Insecurity: Fear, Migration and the Asylum in the EU, London and New York: Routledge, 2006.

${ }^{34}$ Waever, "Abersytwyth, Paris, Copenhagen: New 'Schools in Security Theory and Their Origins between Core and Periphery."
} 
atskleisti šias dèl rutinos atsirandančias praktikas ${ }^{35}$. Tad galima sakyti, kad ir Paryžiaus mokyklos atstovams pagrindinis referentinis objektas lieka individas, tačiau jis yra ịpainiotas ị galybę institucinių praktikų ir tampa jų objektu.

Daugiausia analizuojamos Europos Sąjungos saugumo praktikos nacionalinëje ir tarptautinejje erdvejje, kur ypač ryškus saugumo profesionalejjimas, technokratiškejjimas ir kur reikia užimti specifinę socialinę poziciją, kad galètum „kurti“ saugumą ${ }^{36}$. Pavyzdžiui, pastebima, kokios reikšmingos yra saugumą turinčios stiprinti praktikos: tvirtas (angl. reassuring) kalbẻjimas, saugumo technikos (pavyzdžiui, stebejjimo kameros) ar ịvairios policijos priemonès. Tačiau jos nebūtinai didina saugumą ar stiprina pasitikèjimą politika. Tai priemonès, kuriomis siekiama padidinti saugumo jausmą. Bet šios priemonès kuria nesaugumą, kelia baimès ir netikrumo jausmą tiek individui, tiek bendruomenei ${ }^{37}$.

Europos Sajungos kontekste ryškẻja vidinio ir išorinio saugumo susipynimas. Pavyzdžiui, kai kurios saugumo agentūros, kurioms neskiriama daug dèmesio diskutuojant apie saugumą (policija, muitinè, pasienio apsaugos, imigracijos tarnybos), vis dažniau pasirodo saugumo lauko centre. Jos turi galią reaguoti $\mathfrak{i}$ šiuolaikinius iššūkius ir priimti sprendimus, veikiančius mūsų visų saugumą, arba, kaip, matyt, pasakytų patys atstovai, kuria mūsų nesaugumo jausmą. Bigo šį susipynimą apibūdina Mèbijaus lapo metafora, paaiškindamas, kad „vidus ir išore visada priklausys nuo veikejo žiūrèjimo kampo“ ${ }^{38}$.

Ši tyrimų perspektyva atsispiria nuo sugrèsminimo teorijos idèjų (dèmesio kalbètojams), bet papildo ją ir pabrèžia ne tik kalbejjimo, bet daug labiau darymo - praktikų - analizès svarbą. Pavyzdžiui, klausia, kaip kontroliuojamos sienos, kokiu būdu atsirenkama, ką praleisti, o ko ne (o tai reiškia priima sprendimą, kokioms tapatybems kyla pavojus ir kas jị kelia), kaip apibrèžiamos taisyklès ir kaip jos taikomos. Paryžiaus mokykla analizuoja valdymo technikas ${ }^{39}$, kreipia dèmesị i galios žaidimų pasekmes, tam tikrų valdymo formų

\footnotetext{
${ }^{35}$ Pvz., Bigo D. \& Tsoukala A., eds., Terror, Insecurity and Liberty : Illiberal Practices of Liberal Regimes after 9/11, Routledge, 2008.

${ }^{36}$ C.A.S.E. Collective, op.cit., p. 449-450.

${ }^{37}$ Huysmans, The Politics of Insecurity: Fear, Migration and the Asylum in the EU.

${ }^{38}$ Bigo D., "The Möbbius Ribbon of Internal and External Security" in Albert M., Jacobson D. \& Lapid Y., eds., Identity, Borders, Orders: Rethinking International Relations Theory, Minneapolis: University of Minnesota Press, 2001, p. 91-116 (angl. - „the location of agents (inside/outside) is not fixed“).

${ }^{39}$ Remiasi Michelio Foucault'o governmentality tyrimais, žr., pvz., Foucault M., "Governmentality," in Burchell G., Gordon C.\& Miller P., The Foucault Effect: Studies in Governmentality, London: Harvester Wheatsheaf, 1991, p. 87-104.
} 
radimąsi igalinančius ir ribojančius kontekstus ${ }^{40}$, tiria saugumo profesionalų tinklus, jų konkurenciją, institucinį kontekstą.

Tad matome, kad ir kritinèse saugumo studijose renkamasi ịvairias strategijas, kuriomis skatinamas gilinimasis ị mąstymo prielaidas, saugumo vaidmens valstybių ir individo gyvenimuose refleksija. Velso mokyklos atveju, sąmoningai pasirenkama politine strategija ir kritinè analizè kyla iš normatyvinio, emancipacijos siekio ir noro apsaugoti individą nuo valstybès. Antruoju atveju, analizés objektu pasirenkant institucines praktikas ir tinklus siekiama išnarplioti mechanizmus, per kuriuos tam tikri ar net visi individai tampa saugumo subjektais, atsiranda ne tik kitų naujų saugumo problemų, bet ir naujų saugumo veikejų, kitokios galios, naujų gyvenimo formų.

\section{Saugumo tyrimai}

Toliau pristatomos ir aptariamos trys saugumo tyrimų grupés: saugumo ir rizikos praktikų, saugumo ir ypatingumo ryšio ir saugumo ir medijų sąveikos analizès. Aptariami tematiniai saugumo tyrimai susiję su ankstesnèje dalyje aptartomis prielaidomis. Juos jungia suvokimas, kad saugumo praktikos neatsiejamos nuo politinių praktikų ir sprendimų, kad svarbu analizuoti mąstymo prielaidas ir praktikų pasekmes ir siekia išskirti ir analizuoti ịvairiausius galios mechanizmus, kurie kuria ir naudojasi analizuojamomis saugumo praktikomis. Kiekviena tyrimų kryptis pristatoma apžvelgiant svarbiausius keliamus klausimus ir siūlomas ižvalgas.

\subsection{Saugumas ir rizika}

$\mathrm{XX}$ a. pabaigos - XXI a. pradžios visuomenè - tai rizikos visuomenè. Žinoma, ne šiais laikais pirmą kartą suvokta, kad gyvename netikrumo sąlygomis, tačiau siekis tą riziką valdyti, noras ją suskaičiuoti, ir taip ịvertinti ateitị, mąstyti, kaip ją patraukti savo pusen, ir mastas, kuriuo tai daroma, yra iš tiesų didžiulis. Rizikos vertinimas pirmiausia atsiranda racionalizmo paradigmoje. Daroma prielaida, kad riziką galima suklasifikuoti, ̣̦vertinti kiekybiškai ir tam

\footnotetext{
${ }^{40}$ Bigo D., "Security and Immigration: Towards a Critique of the Governmentality of Unease", Alternatives, 27 (1suppl), 2002, p. 63-92; Huysmans J., "A Foucauldian View on Spill-Over: Freedom and the Security in the EU”, Journal of International Relations and Development, 7 (3), 2004, p. 294-318; Balzacq T., "The Three Faces of Securitization: Political Agency, Audience, and Context”, European Journal of International Relations, 11 (2), 2005, p. 171-201.
} 
tikru mastu numatyti, o elgiantis racionaliai - ją pašalinti. Tokie tyrimai seniai vykdomi ekonomikoje, jie dažnai taikyti formuluojant grèsmių scenarijus strategijos studijose, taip pat versle, ypač draudimo rinkoje.

Kitokị požiūrị siūlo Ulricho Becko rizikos visuomenès teorija. Beckas teigia, kad mes gyvendami vèlyvaisiais moderniais laikais negalime išvengti rizikos. Rizika - tai viena pagrindinių visuomenès savybių. Ji nesuskaičiuojama, visada gali ịvykti katastrofų su pasekmèmis, kurių nei buvo galima numatyti, nei įmanoma kompensuoti. Pavyzdžiui, $2001 \mathrm{~m}$. rugsẻjo 11-osios nebuvo galima numatyti. Tai buvo ịvykis, atskleidęs šiuolaikinių draudimo priemonių ribas. Lygiai kaip nebuvo galima numatyti Azijos finansų krizès, Černobylio katastrofos ar globalios klimato kaitos. Ir lygiai taip pat daugybė procesų, kurie dabar prasidejo (žmogaus genomo tyrimai, nanotechnologijos), turès pasekmių, kurių mes dabar negalime numatyti. ${ }^{41}$ Rizikos yra globalios, bet tai toli gražu nereiškia, kad jos tolygiai pasiskirsčiusios. Beckas labiau nori pabrèžti transnacionalų problemų pobūdị ir tai, kad reikia bendrai jas spręsti. ${ }^{42}$ Pavojai, nesaugumas yra neišvengiama struktūrinè grèsmè, kurią galima išspręsti tik per kosmopolitizmą, derantis dèl normų. ${ }^{43}$

Šios Becko idejjos paskatino „refleksyvaus saugumo“ tyrimus, kuriais siekiama suvokti, kaip valdomos naujosios transnacionalinès rizikos. ${ }^{44}$ Pavyzdžiui, Mikkelis Vedby'us Rasmussenas siekia parodyti, kad rugsėjo 11-osios atakos buvo nauja globalumo išraiška, kuri „kitam“ pasauliui leido įsikišti $\mathfrak{i}$ Vakarų erdvę. Kartu, jo įsitikinimu, šis ịvykis buvo scenarijų, smarkiai ir ịvairiais pavidalais generuotų po Šaltojo karo XX a. paskutiniajame dešimtmetyje, realizacija. Ir pagaliau $2001 \mathrm{~m}$. rugsèjo 11-oji atskleidè ontologini šiuolaikinio pasaulio nesaugumą, kai grèsmès gali taip pat sklisti kaip ir prekyba - nepriklausomai nuo sienų. ${ }^{45}$

Pasaulyje po $2001 \mathrm{~m}$. rugsejjo 11-oji aktuali yra nebe tradicinio saugumo dilema, o refleksyvaus saugumo dilema. Šiuo metu Vakarams nekyla jokios didesnès grèsmès iš kokios nors galybès, tad net neverta diskutuoti apie tai, kad yra siekiama didinti savo saugumą kieno nors sąskaita (tai klasikinès saugumo

\footnotetext{
${ }^{41}$ Beck U., "The Terrorist Threat World Risk Society Revisited", Theory, Culture \& Society 19 (4), 2002, p. $41-42$.

${ }^{42}$ Ibid., p. 42; žr. taip pat Beck U., “The Silence of Words: On Terror and War”, Security Dialogue 34 (3), 2003, p. 255-267.

${ }^{43}$ Plačiau apie tai žr. Boyne R., "Cosmopolis and Risk: A Conversation with Ulrich Beck", Theory, Culture \& Society, 18 (4), 2001, p. 47-63.

${ }^{44}$ Rasmussen, M.V., “'It Sounds Like a Riddle': Security Studies, the War on Terror and Risk”, Millennium,

${ }^{33}(2), 2004$.

${ }^{45}$ Rasmussen M.V., “'A Parallel Globalization of Terror': 9-11, Security and Globalization," Cooperation and Conflict, 37 (3), 2002, p. 323-49.
} 
dilemos problema). Tačiau dabar vis labiau diskusijos dèl konfliktų ir saugumo problemų tampa svarbia mūsų saugumo sąlyga. Tokie, pavyzdžiui, yra klausimai, kada apskritai verta imtis kokių nors priemonių ir kodèl jos vadintinos saugumo. Šitos nuolatinès refleksijos - tai, ties kuo dabar koncentruojamasi mąstant ir formuojant saugumo politiką. ${ }^{46}$ Kitaip tariant, mąstymas apie saugumą vis labiau apibrèžia mus pačius ir mūsų šiuolaikinę visuomenę.

Kitoks požiūris riziką laikoma ne mūsų gyvenimą reguliuojančiu principu, o valdysenos (angl. governance) įrankiu. Ši mąstymą ịkvẻpé Foucault darbai apie governmentality ${ }^{47}$. Ši sąvoka apima mąstymo apie valdymą (angl. government) būdą , kurio nuolatinis tikslas yra kurti tvarkingą ir efektyvią visuomenę. Tad analizuojama, kaip grindžiami faktai, pateikiami skaičiai, kokiais įrodymais remiamasi, kaip kalbama apie valdymą ir jo pagrindimą ir apie tai, kaip veikia panaudojama galia. ${ }^{48}$ Todèl pagrindinis analizès dèmesys yra skiriamas politinių argumentų pagrindimo (angl. rationality) ir politinių technologijų analizei. Analizuojant politinius argumentus apibūdinamos problemos ir jų sprendimo būdai, politines technologijas - techninès priemonės ir praktikos, kuriomis politiniai argumentai virsta valdžios, siekiančios didinti savo ịtaką, veiksmais. ${ }^{49}$

Analizuoti saugumą ir riziką iš šios perspektyvos reiškia analizuoti būdus, kuriais plinta, taikomas rizikos diskursas ir praktikos. Bakeris ir Simonas pastebi dvi rizikos plètros strategijas ${ }^{50}$. Pirmoji yra rizikos sklaida (angl. spreading). Tai pastangos tvarkytis su socialinėmis problemomis naudojant rizikos sąvoką, pavyzdžiui, finansų valdyme, socialinèje politikoje, policijoje ir kariuomenejje, aplinkosaugos politikoje. Antroji - riziką priimanti (angl. embracing) strategija, pagal kurią individai vis labiau ir labiau skatinami prisiimti riziką (pavyzdžiui, privačių pensijų fondų plitimas, azartinių lošimų, ekstremalaus sporto populiarejimas). Čia subjektai savo vertę ígyja per savo gebejjimą valdyti savo riziką. Riziką galima valdyti ir per ịvairius valdymo mechanizmus su(si) kurti saugumą. Tai daroma depolitizuojant saugumo kontekstą arba perkeliant saugumo kalbèjimą ị rinkos erdvę, arba permetant jị individo atsakomybẻn. Ir vienu, ir kitu atveju saugumas, kaip grèsmių valdymas ir analizė, yra išstumiamas technokratinio ir racionalaus kalbejiimo sąskaita.

\footnotetext{
${ }^{46}$ Ibid., p. 328.

${ }^{47}$ Ypač Foucault „Governmentality“. Lietuvių kalboje kol kas terminas neturi priimto vertimo.

${ }^{48}$ Dean M., Governmentality: Power and Rule in Modern Society, 2nd ed., Sage, 2010, p. 24-25.

${ }^{49}$ Merlingen, M., "Foucault and World Politics: Promises and Challenges of Extending Governmentality Theory to the European and Beyond“, Millennium, 35 (1), p.183-184.

${ }^{50}$ Pagal Baker T. \& Simon J., "Embracing Risk," in Baker T. \& Simon J., eds., Embracing Risk: The Changing Culture of Insurance and Responsibility, University of Chicago Press, 2010, p. 2-5.
} 
Saugumas, besiremiantis grèsmių analize, pabrèžia veikejjų ir konfliktuojančių pusių ketinimų svarbą, žvalgybos institucijų veiklą pašalinant grèsmes. Saugumas, besiremiantis rizikos analize, kreipia demesị ị sistemą ir jos savybes (gyventojus, aplinką) reikalauja daug ịvairiausių duomenų, modeliavimo ${ }^{51}$. Siekiama ne tiek eliminuoti riziką, kiek sukurti strategijas, kaip su ja gyventi. Mes nebenaikiname pavojų, bet mobilizuojame skirtingas praktikas, kurios kyla iš siekio sukonstruoti, interpretuoti ir tada jau valdyti atsitiktinumą.

Taigi ị saugumo tyrimus įtraukus rizikos valdymo analizę pakeičiama saugumo logika. Pasukama nuo ịprastesnių dèmesio centrų - tapatybių, teritoriškumo, santykio su kitais konstravimo - i konkrečias laike apribotas situacijas ir bandymą tvarkytis su įvairiausiais iššūkiais ateityje (angl. futures). Tiesa, saugumas visada turi šią laikinę dimensiją - visada yra siekiama apsiginti nuo būsimų grèsmių. Tokios rizikos analizès prisideda prie laiko kontrolès iliuzijos, nuo kalbejjimo apie pavojingą ateitị kreipdamos dèmesị $\mathfrak{i}$ technologijas ir strategijas, kuriomis ateitis laikoma suskaičiuojama, ivertinama ir suvaldoma.

Saugumo studijos, stebèdamos vis intensyvejjanti rizikos diskursą, ten kur anksčiau dominavo politika su dèmesiu grèsmèms, kreipia mūsų žvilgsnị i tokio mąstymo pasekmes: technokratinio ekonomizuoto kalbejjimo dominavimą, valdžios nutolimą nuo dalies saugumo politikos ir refleksyvaus mąstymo būtinybę kompleksiškos „refleksyvios modernybès“ laikais.

\subsection{Saugumas ir ypatingumas}

Antroji apžvelgiama tema - saugumo ir ypatingumo ryšys. Jos tyrẻjai kreipia dèmesị jau nebe ị saugumo sampratos atskyrimą nuo politikos, o ị plintančias saugumo valdymo strategijas.

Naujoji politika - „globalus karas su terorizmu“ - kurị laiką dominavusi daugelio šalių saugumo politikos dienotvarkèse, paskatino ir mąstymą apie tokios saugumo politikos kuriamą ypatingumo situaciją. Ši politika pradejjo ne tik karą Irake, karą Afganistane, bet dèl jos smarkiai sugriežtejo oro uostų saugumas, suintensyvejjo piliečių stebejjimas, profiliavimas, atsirado naujos identifikavimo ir kontrolès technologijos. Teoretikai taip pat pradejjo pabrěžti baimių, ịtarimų stiprẻjimą, saugumo, o ne laisvių ir teisių iškèlimą. Pradèta kabèti, kad pasikeite žaidimo taisyklès, kad vyksta naujo tipo karas ir kad atejo ypatingi laikai, kuriems reikia taikyti ypatingas priemones.

\footnotetext{
${ }^{51}$ Aradau C., Lobo-Guerrero L., Van Munster R., "Security, Technologies of Risk, and the Political: Guest Editors' Introduction”, Security Dialogue, 39 (2/3), 2008.
} 
Ypatingumas, tiksliau jo retorika, buvo ir yra naudojama pateisinant ìvairiausią prievartą, kaip, pavyzdžiui, parode ịvykiai Gvantanamo ar Abu Graibo kalëjimuose, tačiau kartu ji suteikia galimybių kalbèti ir apie migracijos suvaržymą, pilietinių teisių ribojimus, kankinimus ir panašias priemones. Šios tendencijos paskatino pradèti analizuoti pačią ypatingumo, kaip radikalios nesaugumo būsenos, sąvoką ir per jos vartojimą išryškinti saugumo politikos pokyčius ir liberalias demokratines valstybes ištinkančius iššūkius - viena vertus, siekiant išlikti liberalioms, kita vertus, apsaugoti save ir savo piliečius nuo neliberalių visuomenių iššūkio (dominuojanti versija).

Mąstant apie tokias problemas buvo atsigręžta ił prieškario Vokietijos filosofo Carlo Schmitto tekstus. ${ }^{52}$ Jis savo Politinę teologija pradejo dabar jau smarkiai per dažnai naudojama fraze - „suverenas nusprendžia, kas yra ypatinga [padettis]“ („sovereign is he who decides on the exception“) $)^{53}$. Pagal Schmittą, ypatingumas yra radikalaus pavojaus situacija, kuriai nèra numatytas joks ịstatymas, jokia procedūra ar priimtinos reakcijos. Tai pavojingas momentas, kuris neturi precedento, čia nèra žinojimo, neįmanoma numatyti, kas nutiks. Ypatingumas leidžia sukurti fundamentalią egzistencinę būtinybę neribotam suvereno veikimui ir sprendimams. Tai nèra tik „normalios“ politikos papildinys, tai autentiška politinès valdžios išraiška, per kurią galima sukurti naują politinę ir teisinę tvarką. ${ }^{54}$

Tiesa, reflektuojant ypatingumo vietą šiuolaikinès saugumo politikos situacijose „šmitiškoji“ logika nèra pratęsiama, ji yra kritikuojama. Visų pirma parodant, kad kaip tik Schmitto logika yra sékmingai realizuojama nacionalinio saugumo diskursuose. Jie visiškai atkartoja jo schemą: ypatingi laikai ypatingos priemonès. Pagrindinè problema, žinoma, yra tai, kad suverenas (ar jo institucijos) pats skelbia ypatingą situaciją ir pats ją apibrežia.

Ypatinga situacija, kaip ir sugrèsminimo situacija ar rizikos apibrèžimas, nekyla dèl objektyvių, natūralių priežasčių, bet dèl to, kad yra prisiskiriama galia apibrèžti ypatingumą, kuris neišvengiamai anksčiau ar vẻliau pradeda sietis su autoritarinėmis priemonemis, abejotinais politiniais sprendimais ir praktikomis. Kadangi ši legitimi galia kyla iš suvereniteto (valdžios), atsiranda būtinybė analizuoti sąlygas, kaip ji yra pritaikoma ir kokiu būdu bei mastu. ${ }^{55}$

Mąstymas apie ypatingumą, iš jo kylančius laisvès suvaržymus siejasi su

\footnotetext{
${ }^{52}$ Schmitt C., Political Theology: Four Chapters on the Concept of Sovereignty, Chicago: University of Chicago Press, 2010; Schmitt C., The Concept of the Political: Expanded Edition, Chicago: University of Chicago Press, 2008.

${ }^{53}$ Schmitt, Political Theology, 5.

${ }^{54}$ Schmitt, Political Theology.

${ }^{55}$ C.A.S.E. Collective, p. 465.
} 
stebejjimo (angl. surveillance) technikų ir jų pasekmių analize. ES Septintosios bendrosios programos projektas "Challenge: Liberty \& Security ${ }^{\text {“56 }}$ - vienas iš ryškesnių bandymų pastaraisiais metais suvokti, kaip nesaugumo diskursas ir stebejimo technologijos veikia piliečiu laisvés ribas (visų pirma Europos Sajungoje) ${ }^{57}$. Projekto tyrèjai suformulavo neliberalių (angl. illiberal) praktikų terminą, kuriuo apibūdinamos situacijos, kai pasirenkama ne laisvès, o saugumo ir ypatingos situacijos retorika. ${ }^{58}$

Pastebima, kaip stipreja itarumas, kai policija nebera atskaitinga teisminei valdžiai, kaip vis labiau plinta stebejimo technologijos, kurias naudoja ne tik valdžia stebėti savo piliečiams, bet ir patys piliečiai tarpusavyje (pavyzdžiu gali būti apsaugos sistemos namuose, kur visi gyventojai turi priejjimą prie stebejjimo kamerų). ${ }^{59}$ Saugumas tampa nebeatsiejamas nuo stebejjimo ir per ji ypatingumas tampa norma.

Bet kokia būtinybe politikoje yra politinis sprendimas, o ne egzistencinè sąlyga. Nèra savaime suprantama, kaip turi būti reaguojama ị konkretų i̇vykị ar situaciją, nèra objektyvių kriterijų, kurie nurodytų, kad reikia taikyti ypatingą atsaką, pavyzdžiui, jei yra varžomos pilietinès teisès. Tai yra politinis sprendimas ir tokiu turi likti, neatiduodant jo biurokratiniam technokratiniam laukui. Todèl šios temos tyrejjai skatina klausti, kaip yra apibrèžiamas padèties ypatingumas, kaip ypatingumo praktikos ir teiginiai tampa pripažizstami, autorizuojami. Kokios institucinès, komunikacinès, socialinès praktikos prie to prisideda? Ir pagaliau kokios visų šių procesų politinès pasekmès.

Taip pradeję nuo ypatingumo erdvès plètimo ir valstybės galios kritikos, ypatingumo situacijas analizuojantys visgi jž̌velgia panašią tendenciją, kaip diskusijose dèl būdų, kaip identifikuoti, atpažinti saugumo situacijas. Politinio sprendimo galią keičia technologijos ar specializuotų diskursų ir praktikų galia. Ir kaip šiuose kompiuterių algoritmų ir biurokratinių veiksmų tinkluose dingsta piliečio laisvių ideja.

\footnotetext{
${ }^{56}$ Challenge - tai projekto santrumpa, kuri išsišifruoja kaip „The Changing Landscape of European Liberty and Security“ (Bekintantis Europos laisvès ir saugumo „peizažas“).

${ }^{57}$ Žr. informaciją apie ši projektą internete www.libertysecurity.org, 20131121.

${ }^{58}$ Bigo and Tsoukala, op.cit..

${ }^{59}$ Didier Bigo et al., The Changing Landscape of European Liberty and Security: Mid-Term Report on the Results of the CHALLENGE Project, Research Paper, Challenge: Liberty \& Security, 2007, http://libertysecurity.org/IMG/pdf_ChallengeMidReport.pdf, 20131121.
} 


\subsection{Saugumas ir medijos}

Diskusijas apie medijų, naujųjų technologijų poveikị saugumui ir jų ryši pradejo Jeanas Baudrillardas knygoje The Gulf War did not Take Place („Persijos ilankos karo nebuvo“). Baudrillardas apvertė XIX a. karo teoretiko Carlo von Clausewitzo garsiąją frazę, sakydamas, kad analizuojamas karas buvo „politikos nebuvimo tąsa kitomis priemonemis ${ }^{\text {“ }}{ }^{60}$ Kaip Sadamas Husseinas nekovojo su jungtinemis pajègomis, o naudojo savo karius savo valdžiai išsaugoti, taip ir jungtinès pajėgos tiesiog mèté kasdien bombas tarsi įrodinėdamos, kad kovoja su priešu. Prie šio žaidimo labai prisidejo Vakarų žiniasklaida, rodydama karą tiesiogiai naudodama tuos pačius karo vaizdus lyg norèdama visiems įrodyti, kad JAV vedama koalicija iš tiesų kariauja su Iraku šiuo metu. Anot Baudrillardo, taip iš tiesų nenutiko. Irakas nesusilpnèjo, ir apskritai mažai kas po karo ir dèl jo pasikeitè. Tad šia prasme karas neįvyko - nors mes ir matėme ji vykstant.

Anot Martino Shaw'o, po Persijos ịlankos karo suvokta, kad galima karus kariauti ir padedant žiniasklaidai, kuri nebūtinai turi parodyti daug aukų ar kančių ${ }^{61}$. Karų ir konfliktų mediacija tapo neatsiejama konfliktų dalimi. Net sugalvota nauja sąvoka - „sporto aistruolio karas“ (angl. spectatorsport-war), kuria ironiškai pastebima, kad Vakarų valstybès kariauja iš toli, besistengdamos kiek galima mažiau įtraukti savo karių tiesiogiai. Visuomenẻ nedalyvauja, ji stebi iš toli. Kaip ir sporto žiūrovai, ne visi stebi vienodai - vieni paviršutiniškai, kiti bandydami suprasti taktiką, strategiją. Bet svarbiausia, kad jų visų potyriai yra atitolę. Jie užjaučia, nekenčia kartu, jie gali jausti ir empatiją, bet patyrimas yra toli, nejuntamas ${ }^{62}$. Tad nutolimas ir reprezentacijų kovos kuria savo saugumo suvokimą ir poreikius, kartu jos kuria ir azartą, kuris perkoduoja kitų nesaugumo jausmą ne tik ị savojo (ne)saugumo suvokimą, bet ir i pramogą, vartojimo objektą.

Jamesas Deras Derianas kiek vèliau šią socialinę sistemą, sudarytą iš karo, technologijų, žiniasklaidos ir mūsų žiūrèjimo, pavadins MIME kompleksu (angl. military-industrial-media-entertainment). ${ }^{63}$ Stiprëjanti karo mediacija verčia kalbèti apie virtualų karą. Anot Der Deriano, vis intensyvejjanti technologine karo mediatizacija sukuria fiziškai neegzistuojantị karą. Virtualus karas tampa ne tik ji stebintiems, jis tampa tokiu ir patiems karo daly-

\footnotetext{
${ }^{60}$ Baudrillard J., The Gulf War Did Not Take Place, Indiana University Press, 1995.

${ }^{61}$ Shaw M., The new western way of war: Risk-transfer war and its crisis in Iraq, Polity, 2005, p. 37.

${ }^{62}$ McInnes ideja, pateikiama pagal Peoples \& Vaughan-Williams, op.cit., p. 153.

${ }^{63}$ Der Derian J., Virtuous War: Mapping the Military-Industrial-Media-Entertainment-Network, Routledge, 2009.
} 
viams - pavyzdžiui, taip technologijų operatoriai, valdytojai dalyvauja virtualioje realybeje. Der Derianui virtualumas konstruoja pasauli ne iš nieko, o iš mašinos - ten, kur nieko prieš tai nebuvo. Čia atsikartoja ir Baudriallardo idèja apie simuliakrų pasaulị. Esminis virtualumo bruožas yra mėgdžioti ir taip kurti realybę iš informacijos, kuri šiuolaikinių technologijų dèka gali būti perduodama greitai ir ịvairiai simuliuojama. Vis svarbiau yra veikti iš toli, o tai reiškia būti priklausomam nuo tikslios informacijos, tikslios signalų, vaizdų, duomenų kompiuterio ekrane interpretacijos.

Šioje vietoje pradedama kalbèti apie „reikšmès saugumą“ (angl. security of meaning). Der Derianas stengiasi pabrežti, kad virtualusis karas turi kūniškų, apčiuopiamų pasekmių tiems, kurie yra priešininkai, visų tų technologijų „išbandytojai“ (taip vadinamasis collateral damage). Ir jų netikrumas vienai pusei nepadaro virtualiojo karo mažiau tikru kitiems. Tačiau kitiems, esantiems kitur, medijos panaikina atstumą, ir kartu karas tampa saugesnis, paprastesnis, kariai atitraukiami nuo karo baisumų, ten jau nebe žmonès o mirksintys taškai ekrane. Karų mediacija nẻra vien tik Vakarų būdas reprezentuoti ir interpretuoti savo konfliktus. Karo vaizdai yra skleidžiami po visą pasaulį. Žiniasklaidos valdymas (angl. media menagement) tampa svarbia saugumo ir karinių veiksmų dalimi. Kinta ne tai, kad žiniasklaida yra ịtraukiama ị pasakojimus apie karus ir konfliktus, o veiksmų mastas ir pobūdis. Šios tradicijos tyrejai analizuoja reprezentacijų technikas, skirtingas mediacijos formas ir kaip didžioji dalis kritinių pozicijų siekia parodyti saugumo reikšmę kasdieniame gyvenime ir kasdieniuose valstybių veiksmuose.

\section{Kaip ir ką panaudoti?}

XXI a. nepaisant išliekančių „tradicinių“ grèsmių, vis sunkiau yra išgyventi mąstant nacionalinio saugumo paradigmos rẻmuose. Net jei ir atsisakoma siauro karinio požiūrio ị saugumą, saugumo problemų skaičiaus didejjimas ne tik sukelia paties saugumo nuvertejimą, bet dar svarbiau, kad priverčia mąstyti apie tiesiogines saugumo politikos pasekmes. Saugumo politikos praktikams teorijų ir teorinių svarstymų laukas atrodo nutolusi, uždara, kartais net hermetiška erdvè. Tačiau kartu saugumo studijos yra neatsiejama nuo praktinių klausimų ir iš tiesų labai glaudžiai susijusios su praktiniais iššūkiais, jų refleksija.

Bene svarbiausia kritinių saugumo studijų dalis yra susijusi su teorijos apmąstymu ir politinių praktikų prielaidų analize. Taip saugumo politika užsiimantys asmenys skatinami tapti refleksyvesniais, ịvertinti mąstymą apie 
savo veiklą, praktiką, kasdienius veiksmus ir jų pasekmes. Kritinè perspektyva rodo, kaip galima išgyventu su įvairiausiomis tiesoms, pozicijomis ir techninėmis žiniomis, kaip jos dera ar nedera tarpusavyje ir kokių pasekmių turi ¿̇vairūs veiksmai, kaip veikti ir mąstyti daugialypejje, prieštaringoje aplinkoje, kurioje yra skirtingų tiesų, daugybè teorijų ir žinojimo formų. Nekalbant jau apie tai, kad net priverstinai raginama kelti etinius klausimus - kodèl kažką vadiname saugumo problema, kas atsitinka, kai suformuluojame naują saugumo problemą ir kodèl tai darome, kaip visa tai sprendžiame.

Lietuvos saugumo politikos tyrimų kontekste galime nagrinèti ir klausti, koks turètų būti valstybès saugumo politikos tikslas, kaip keičiasi vidinio ir išorinio saugumo santykis, kokios valstybės institucijos šiuo metu rūpinasi saugumu, kaip jos tai daro ir kaip jų konkurencija veikia jų pačių veiksmus ir požiūrị i ̣ piliečius. Kaip Lietuvos saugumo institucijos įsitraukè ị ES institucijų tinklus ir kokie iššūkiai joms kilo ar kyla. Kokia ịtampa formuojasi tarp valstybès institucijų ir individo saugumo ir laisvių? Kokie ypatingumo diskursai yra naudojami pateisinant, pagrindžiant nacionalinio saugumo strategijas, užsienio politikos pasirinkimus, kokio pobūdžio atvirumą ir kiek jo leidžia? Kaip mūsų saugumo suvokimą keičia naujausios technologijos, ypač medijos. Kaip mes kalbame ir vertiname gyvenimo šalyje ir su kaimynais riziką.

Apžvelgta saugumo analizè siūlo kitokị saugumo tyrimą, kurio metu keliami ir nagrinejjami kitokie klausimai, problemos, iššūkiai. Suprantama, kad individo saugumo užtikrinimas turi būti galutinis visų politinių veiksmų tikslas. Tačiau, kad saugumas liečia realius žmones, kartu reiškia ir tai, kad saugumo studijos turi analizuoti ir kasdienybeje egzistuojančius suvaržymus, kliūtis, trukdančias žmonių veikimui ir raiškai. Daugybė socialinių praktikų, ì kuriuos atkreipia dèmesị rizikos tyrèjai, viena vertus, šiais laikais individui primeta vis didesnę atsakomybę už savo gyvenimą ir pasirinkimus, kita vertus, per platų institucinį tinklą sukuria daug suvaržymų ir apribojimų, kuriuos ir skatinama analizuoti. Ypatingos padèties kūrimas ir valdžios institucijų noras technologijomis kontroliuoti visuomenę ir būtent per kontrolę kurti saugumą reiškia, kad būtina suvokti ypatingumo reikšmę šiuolaikinèje politikoje. Pagaliau medijos, virtualiosios erdvès, nuotolinès technologijos - tai reiškiniai, per kurių analizę galime suvokti ne tik kariavimo priemonių efektyvejjimą, bet ir saugumo politikos plitimą ỉ mūsų kasdienybę ir saugumo institucijų priartejjimą prie žmogaus asmeninès erdvės ir jo gyvenimo kontrolès. 